\title{
Biology Teacher's Knowledge About Discovery Learning and Team Assisted Individualization Model Based on Teaching Experience
}

\author{
Riski Rusmalinda ${ }^{1, *}$ Paidi $^{2}$ \\ ${ }^{1}$ Master of Biology Education, Faculty of Mathematics and Natural Sciences, Universitas Negeri Yogyakarta, \\ Indonesia \\ ${ }^{2}$ Department of Biology Education, Faculty of Mathematics and Natural Sciences, Universitas Negeri \\ Yogyakarta, Indonesia \\ *Corresponding autho. Email: riskirusmalinda.2019@student.uny.ac.id
}

\begin{abstract}
This research was descriptive study that aims to describe the biology teachers knowledge about Discovery Learning and Team Assisted Individualization learning model is based on teaching experience of Public Senior High School/Islamic Senior High School (SMAN/MAN) in Metro City Lampung Province. This research was conducted at May to September 2020. The research subjects was all biology teachers at Public Senior High School/Islamic Senior High School (SMAN/MAN) in Metro City Lampung Province. The instrument was used a written test. The data collection used a multiple choice written test with five alternative answers. Test instrument used the dimensions of understanding according to Anderson et al. The results showed that biology teachers knowledge about Discovery Learning model was higher than the Team Assisted Individualization (TAI) learning model. Based on teaching experience, biology teachers has very high knowledge of Discovery Learning model in work period 10-20 years, while biology teachers has high knowledge of Team Assisted Individualization learning model in work period 31-41 years.
\end{abstract}

Keywords: Biology teacher's knowledge, Discovery learning, Team assisted individualization, Teaching experience

\section{INTRODUCTION}

Education in 21 st century has a responsibilities to manifest a generation which are critical thinking, problem solving, collaboration, creativity and innovation [1], [2]. The student have to achieve 21st skills in order to make them individually skilled in taking a chance of the competition and solve problems in real life [3]. Problem solving of the student could be guided by a teacher, because they are the important element of education system which is influence the creation of process and quality of education result. Hence, a teacher should have arrange skills and implementing various strategies and learning model to ensure the effectiveness of learning [4]. Implementation of learning model is related to the role of teacher to determine the effectiveness and efficiency of learning activities [5] so that, it is created a learning process which is appropriate with education purposes.
The role of teachers as an educator is inseparable from how teachers can carry out the learning process that can motivate students. In achieving the learning process, so teacher have good knowledge of learning model to be used, so teacher will easier to implement the learning model that will be used.

The ability to design and implement a learning strategy requires the performance and experience of a teacher. Teaching experience is releted to the teacher's ability to carry out the learning process [6]. Teacher with longer tenure are expected to have a lot of experience. Experienced teachers will have good knowledge and be able to manage the class well, so that it will support the success of students in achieving their learning achievements [7]. The teaching experience of a teacher can be measured based on the teacher's ability to transfer knowledge to students [8]. Experienced teachers can manage the learning process effectively and motivate students [9]. Teaching experience can improve teacher 
professionalism in transferring knowledge for the better, so that teachers become more qualified.

The increased experience a teacher has in teaching; the teacher will have a lot of knowledge. Teacher knowledge can be increased through regular training activities (workshops) in an effort to harmonize the times and developments in the applied curriculum. Currently the learning process uses the 2013 curriculum to practice skills in the 21 st century. The 2013 curriculum emphasize learning that is student centered and learning with scientific nuances [10].

One of learning model that student centered is the Discovery Learning model and the Team Assisted Individualization learning model. Discovery Learning is a learning model that allows student to be directly involved in learning activities, through discovery activities students can build their own knowledge by experiment [11], [12]. The Team Assisted Individualization learning model is combination of cooperative and individual learning models, this model emphasizes group learning to help each other, discuss, argue, improve knowledge to eliminate gaps between students [13], [14].

The Discovery Learning and Team Assisted Individualization learning model emphasize student centered activities that are accordance with the characteristic of the 2013 curriculum. To implementation this learning model it requires teacher knowledge about the Discovery Learning and Team Assisted Individualization learning model so that the learning process becomes more effective. To achieve effective learning, a teacher's teaching experience is needed, in this case the teaching experience namely the teacher's working period in carrying out duties as educator in educational units.

In carrying out a quality learning process, it requires experience and knowledge of teachers about learning model. Teachers' knowledge of the learning model will affect the quality of learning and the success of student [15]. Therefore, the teachers' knowledge of the Discovery Learning and Team Assisted Individualization learning model based on teaching experience needs to be. So far no information about the biology teacher's knowledge of Discovery Learning and Team Assisted Individualization learning model based on teaching experience in Metro City Lampung Province, so this research is interesting to do to obtain an empirical picture of the level of biology teacher's knowledge on learning model based on teaching experience.

\section{RESEARCH METHODS}

\subsection{Research Design}

This research was a descriptive study with the census method that aims to describe the biology teacher's knowledge of Discovery Learning and Team Assisted Individualization based on teaching experience at Public Senior High School/Islamic Senior High School (SMAN/MAN) in Metro City Lampung Province. Subject of this research was all biology teachers at Public Senior High School/Islamic Senior High School (SMAN/MAN) in Metro City Lampung Province, totaling 27 teachers. This research was conducted at Public Senior High School/Islamic Senior High School (SMAN/MAN) in Metro City Lampung Province on May until September 2020.

\subsection{Data Collection Techniques and Instrument}

This research obtained primary data about the biology teacher's knowledge of the Discovery Learning and Team Assisted Individualization learning model based on teaching experience. Primary data were obtained directly from the questionnaires distributed to the subject of this research. Primary data were obtained directly using collection techniques data in the form of a reasoned multiple-choice test. The instrument test used a dimensions of understanding test based on Blooms' taxonomy, that covers: interpreting, giving examples, classifying, summarizing, concluding, comparing, and explaining [16]. From these indicators, 20 questions are obtained in the form of multiple-choice with five alternative answers. The questionnaire in this study consisted of 10 questions related to Discovery Learning model and 10 questions related to Team Asisted Individualization (TAI) model. Before used the instrument, the validity and reliability tests were carried out. The validity test was carried out using face validity by expert judgement and the reliability test was carried out using the formula Cronbach's Alpha.

\subsection{Research Data Analysis Techniques}

The data obtained were then grouped based on teaching experience to obtain 3 groups with a span of 10 years in each group of teaching experience, that covers 10-20 years, 21-30 years, and $31-40$ years. Then the data obtained were analyzed and categorized based on the scores obtained [17]. The criteria for teacher understanding can be seen in Table 1. 
Table 1. Criteria for understanding indicators.

\begin{tabular}{|c|c|}
\hline Range of score & Criteria \\
\hline $75<\mathrm{X}$ & Very high \\
\hline $58.35<\mathrm{X} \leq 75$ & High \\
\hline $41.65<\mathrm{X} \leq 58.35$ & Moderate \\
\hline $25<\mathrm{X} \leq 41.65$ & Low \\
\hline $\mathrm{X} \leq 25$ & Very low \\
\hline
\end{tabular}

Table 2. Biology teachers' knowledge of the discovery learning and team assisted individualization models.

\begin{tabular}{l|c}
\hline earning Model & Score \\
\cline { 2 - 2 } Discovery Learning & 69 \\
\hline \multicolumn{2}{|c|}{ Team Assisted Individualization } \\
\hline \multirow{2}{*}{ 3. RESULTS AND DISCUSSION } \\
3.1. Biology Teacher's Knowledge of the \\
Discovery Learning and Team Assisted \\
Individualization Learning Model
\end{tabular}

Biology Teacher's knowledge the Discovery Learning and Team Assisted Individualization (TAI) learning models obtained data as shown in Table 2.

The result of research of biology teacher's knowledge at public senior high school/Islamic high school (SMAN/MAN) in Metro City Lampung Province of the Discovery Learning and Team Assisted Individualization as seen in Table 2, show that the biology teacher's knowledge of the Discovery Learning has mean score 69, maximum score 100, minimum score 20, and standard deviation 21,27. Based on the mean score it show that the biology teacher's knowledge of public senior high school/Islamic high school (SMAN/MAN) in Metro City Lampung Province on the Discovery Learning model is high.

Then the level of biology teacher's knowledge of the Team Assisted Individualization learning model show mean score 58 , maximum score 80 , minimum score 30 and standard deviation 15,16 . Based on the mean score it show that the biology teacher's knowledge of Team Assisted Individualization is moderate.

Based on the result of the study, it show that the biology teacher's knowledge in public senior high school/Islamic senior high school (SMAN/MAN) of the Discovery Learning model is higher than the biology teacher's knowledge of the Team Assisted Individualization learning model. This is per with the data obtained, that most biology teacher know better and have implemented the Discovery

\begin{tabular}{|c|c|c|c|}
\hline \multicolumn{3}{|c|}{ f Biology Teacher Understanding } & \multirow[t]{2}{*}{ Criteria } \\
\hline Max & Min & Std. Dev & \\
\hline 100 & 20 & 21.27 & High \\
\hline 80 & 30 & 15.16 & Moderate \\
\hline
\end{tabular}

Learning model compered Team Assisted Individualization learning model. Teacher's knowledge about learning model is important to be able to related management of the learning process, such as implementing learning strategies/models that will be used to create a quality learning process [18].

\subsection{Biology Teacher's Knowledge of the Discovery Learning and Team Assisted Individualization Learning Models based on Aspects of the Learning Model}

Biology Teachers' knowledge of the Discovery Learning and Team Assisted Individualization learning models can be reviewed based on aspect of the learning model that have been adapted to the dimensions of understanding based on Bloom's taxonomy that are interpreting, exemplifying, classifying, summarizing, inferring, comparing, explaining [16]. This research only used five dimensions of understanding, that are interpreting, exemplifying, summarizing, classifying and inferring.

\subsubsection{Biology Teacher's Knowledge of the} Discovery Learning Model based on aspects of the Learning Model.

The results of biology teacher's knowledge at senior high school/Islamic senior high school (SMAN/MAN) of the Discovery Learning model based on aspects of learning model in table 3 show that the mean score of biology teachers' knowledge of the definition aspect of learning model is 78 criteria was very high, in the aspect of applying the learning model is 44 moderate criteria, the characteristic aspect of learning model is 50 with moderate criteria, the syntax aspect of the learning 
Table 3. Biology teacher's knowledge of the discovery learning based on aspect of the learning model

\begin{tabular}{|c|c|c|c|c|c|c|}
\hline \multirow[t]{2}{*}{$\begin{array}{l}\text { Understanding } \\
\text { Dimension }\end{array}$} & \multirow[t]{2}{*}{$\begin{array}{l}\text { Aspects of Discovery Learning (DL) } \\
\text { Model }\end{array}$} & \multicolumn{4}{|c|}{$\begin{array}{l}\text { Score of Biology Teacher } \\
\text { Understanding }\end{array}$} & \multirow[t]{2}{*}{ Criteria } \\
\hline & & Mean & Max & Min & $\begin{array}{l}\text { Std. } \\
\text { Dev }\end{array}$ & \\
\hline Interpreting & Definition of Model DL & 78 & 100 & 0 & 42.77 & Very high \\
\hline Exemplifying & Application of Model DL & 44 & 100 & 0 & 51.13 & Moderate \\
\hline Summarizing & Characteristics of Model DL & 50 & 100 & 0 & 29.7 & Moderate \\
\hline Classifying & Syntax of Model DL & 76 & 100 & 25 & 21.81 & Very high \\
\hline Inferring & Strengths and weaknesses of Model DL & 83 & 100 & 0 & 38.34 & Very high \\
\hline
\end{tabular}

model is 76 with criteria very high, then the aspects of strengths and weaknesses learning model is 83 with criteria very high.

Based on the mean score, it show that the biology teachers of senior high school/Islamic high school (SMAN/MAN) in Metro City Lampung Province had very high knowledge on the aspects of defining the learning model, mentioning the syntax of the learning model and explaining the strengths and weaknesses of the learning model. This show that the biology teacher has excellent initial concept knowledge about the Discovery Learning model.

Then in the aspect of explaining application of learning model and mentioning characteristics of learning model, the level knowledge of biology teacher at public senior high school/Islamic senior high school in Metro City is moderate criteria. Biology teacher's knowledge of learning model canaffect their ability to plan learning activities. So it is important for a teacher to understand a learning model in order to create quality learning process.

\subsubsection{Biology Teacher's Knowledge of the \\ Team Assisted Individualization Learning (TAI) Model based on Aspects of the Learning Model.}

The results of biology teacher's knowledge of the Team Assisted Individualization (TAI) learning model based on aspects of the learning model can be seen on Table 4.
The results of biology teacher's knowledge of the Team Assisted Individualization learning model based on table 4, show that the mean score in definition aspect of the learning model is 67 with high criteria, in this aspect application of the learning model is 83 with very high criteria, in the characteristics aspects of the learning model the mean score is 56 with moderate criteria, in the syntactic aspect of the learning model the mean score is 48 with moderate criteria, and in the aspects of the strengths and weaknesses learning model the mean score is 58 with medium criteria.

Based on the results of the mean score obtained, it showed that the biology teacher's knowledge of the Team Assisted Individualization (TAI) model had a very high knowledge in the aspect of explaining the implementation of the learning model. In the aspect of explain the definition learning model, the level if teacher knowledge is high. In the aspect of mentioning the characteristics of the learning model, mentioning the syntax if learning model and explaining the strengths and weaknesses of learning model, the level of biology teacher's knowledge is medium criteria.

The level of knowledge of biology teachers on every aspects of the learning models was different, because not all biology teachers were familiar and apply the Team Assisted Individualization learning model in the learning process. It was shown by the result of questioner which were conducted by every biology teacher in Metro City Lampung Province

Table 4. Biology teacher's knowledge of the team assisted individualization based on aspect of the learning model

\begin{tabular}{|c|c|c|c|c|c|c|}
\hline \multirow[t]{2}{*}{$\begin{array}{l}\text { Understanding } \\
\text { Dimension }\end{array}$} & \multirow{2}{*}{$\begin{array}{l}\text { Aspects of Team Assisted } \\
\text { Individualization (TAI) Model }\end{array}$} & \multicolumn{4}{|c|}{$\begin{array}{l}\text { Score of Biology Teachers } \\
\text { Understanding }\end{array}$} & \multirow[t]{2}{*}{ Criteria } \\
\hline & & Mean & $\operatorname{Max}$ & $\operatorname{Min}$ & $\begin{array}{l}\text { Std. } \\
\text { Dev }\end{array}$ & \\
\hline Interpreting & Definition of Model TAI & 67 & 100 & 0 & 48.5 & High \\
\hline Exemplifying & Application of Model TAI & 83 & 100 & 0 & 38.34 & Very High \\
\hline Summarizing & Characteristics of Model TAI & 56 & 100 & 0 & 22.86 & Moderate \\
\hline Classifying & Syntax of Model TAI & 48 & 100 & 0 & 32.78 & Moderate \\
\hline Inferring & $\begin{array}{c}\text { Strengths and weaknesses of } \\
\text { Model TAl }\end{array}$ & 58 & 100 & 0 & 39.29 & Moderate \\
\hline
\end{tabular}


Table 5. Biology teacher's knowledge of discovery learning model based on teaching experience

\begin{tabular}{|c|c|c|c|c|c|}
\hline \multirow{2}{*}{ Teacher Experience (year) } & \multicolumn{6}{|l|}{ Score of Biology Teacher Understanding } & \multirow{2}{*}{ Criteria } \\
\cline { 2 - 5 } & Mean & Max & Min & Std. Dev & \multirow{2}{*}{ Very high } \\
\hline $10-20$ years & 82,50 & 100 & 60 & 15.81 & Moderate \\
\hline $21-30$ years & 55 & 80 & 20 & 19.88 & High \\
\hline $31-40$ years & 75 & 90 & 60 & 7.07 & \\
\hline
\end{tabular}

\subsection{Biology Teacher's Knowledge of the Discovery Learning and Team Assisted Individualization (TAI) Learning Model based on Teacher Experience}

\subsubsection{Biology Teacher's Knowledge of} Discovery Learning Model based on Teaching Experience.

In this case, biology teacher's knowledge of the learning model can be seen based on teaching experience, because teaching experience in this research was the period of work as a teacher. The result of biology teacher's knowledge of the Discovery Learning based on their teaching experience can be seen in table 5 .

Biology teacher's knowledge of Discovery Learning model based on teaching experience, in table 5 showed that in work periode $10-20$ year, level of biology teacher's knowledge is very high with mean score 82.50 . In work periode $21-30$ years has the mean score 55 with moderate criteria, then in work period 31-40 years the level of biology teacher's knowledge has mean score 75 with moderate criteria.

Based on the mean score show that there are differences in biology teacher' knowledge of the Discovery Learning model based on teaching experience. Teachers with work period 10-20 years have very high level knowledge about Discovery Learning model. In work period 21-30 years teacher have a moderate criteria. While in work period 31 40 years teacher have high knowledge. The length of time work as a teacher will provide a different experience from another teacher.

In work period 10-20 years, teacher have very high knowledge of Discovery Learning model because teacher still passionate about developing understanding and teaching skills effectively. Novice teachers get positive feedback from students so the teacher are more motivated and enthusiastic in improving their quality [19].

In work period 31-40 years, teacher has a high level of knowledge about Discovery Learning model. A teacher who has a longer work period is able to improve his/her teaching experience because more information and new knowledge is obtained by the teacher [20]

The teaching experience of a teacher has an important role in the success of the educational process. Increasing the teaching experience of a teacher, there are many teaching methods that can be used in the learning process that can increase teacher's knowledge of various learning models, so that the teacher's knowledge will be better knowledge [21]. Teaching experience is one of factors that can support the implementation of learning activities. Increasing teacher experience

Table 6. Biology teacher's knowledge of team assisted individualization learning model based on teaching experience

\begin{tabular}{|c|c|c|c|c|c|}
\hline \multirow{2}{*}{ Teacher Experience (year) } & \multicolumn{6}{|l|}{ Score of Biology Teacher Understanding } & \multirow{2}{*}{ Criteria } \\
\cline { 2 - 5 } & Mean & Max & \multicolumn{1}{l|}{ Min } & Std. Dev & High \\
\hline $10-20$ years & 63.75 & 80 & 40 & 15.05 & Moderate \\
\hline $21-30$ years & 47.14 & 70 & 30 & 12.63 & High \\
\hline $31-40$ years & 65 & 70 & 60 & 7.07 & \\
\hline
\end{tabular}

makes teachers understand more about various strategies in managing learning in class. 
3.3.2. Biology Teacher's Knowledge of the Team Assisted Individualization (TAI) Learning Model based on Teacher Experience.

The results of the research of the biology teacher's knowledge of Team Assisted Individualization (TAI) learning model based on teaching experience could be seen on Table 6 .

Results of the research of biology teachers knowledge on Team Assisted Individualization (TAI) learning model based on teaching experience in Table 6 shows the mean score in work period 1020 years is 67.75 with high criteria. Work periode 21-30 years has the mean score 47.14 with moderate criteria, then in work periode 31-40 years has the mean score 65 with high criteria.

Based on the mean score, it show that there are differences in biology teacher's knowledge about Team Assisted Individualization learning model. Teacher with work period $10-20$ years have high knowledge. Teachers with work period 21-30 years have moderate knowledge. Then teacher with work period 31-40 years have the highest knowledge.

In work period 10-20 years teacher has high knowledge of Team Assisted Individualization because teacher still passionate about developing understanding and teaching skills effectively. Novice teachers get positive feedback from students so the teacher are more motivated and enthusiastic in improving their quality [19].

The biology teacher's knowledge in work period 31-40 years have highest score, this showed that the longer teacher's teaching experience, more experience he/she gets so that he/she has a better understanding. According with research [22] teacher with longer work period have better knowledge. Teaching experience is the experience of a teacher in carrying out their duties as an educator, generally teaching experience can affect a teacher's performance and increase the work ability of teachers to achieve learning purposes. Teachers with longer work period have many opportunities to develop skills through direct experience so that they have better knowledge [23] [24]. The teaching experience of a teacher can determine the achievement of learning outcomes that will be achieved by students.

Teachers who have teaching experience will be better at carrying out learning activities in class because experienced teachers will find it easier to deal with problems in the learning process related to learning materials or in learning strategies. In some cases, teachers who have a longer teaching experience will have more experience in carrying out learning activities when compared to teachers who are relatively new [19]. Longer work period, a teacher has more teaching experience, teaching experience is obtained by the teacher through things experienced in learning activities, both regarding knowledge or skills, if in teaching the teacher finds something new then the teacher will get a lot of additional knowledge and skills regarding their field of work.

\section{CONCLUSION}

The results of the research of biology teacher's knowledge at public senior high school/Islamic senior high school (SMAN/MAN) in Metro City Lampung Province of the Discovery Learning model and Team Assisted Individualization learning model get different results. The level knowledge of the biology teacher in the Discovery Learning model is in the high category, while the Team Assisted Individualization model knowledge is in the medium category. Teachers' knowledge of the Discovery Learning and Team Assisted Individualization models based on teaching experiences have different levels of knowledge. In the Discovery Learning model the teacher has very high knowledge during the work period of 10-20 years, while in the Team Assisted Individualization (TAI) model with a work period of 31-40 years has a high category in the level of knowledge and understanding.

\section{ACKNOWLEDGMENTS}

The author would like thanks to God, Yogyakarta State University, the biology teacher of public senior high school/Islamic senior high school (SMAN/MAN) in Metro City Lampung Province, and my family for their assistance, support, and collaboration during the research process.

\section{REFERENCES}

[1] A.R. Saavedra, V.D. Opfer, Learning 21stCentury Skills Requires 21st-Century Teaching, Phi Delta Kappan 94 (2012) 8-13. DOI: https://doi.org/10.1177/003172171209400203

[2] National Education Association, Preparing 21st Century Students for a Global Society: An Educator's Guide to the "Four Cs", Great Public Schools for Every Student, 2010, Accessed on: Oct. 2020, [Online]. Available: http://www.nea.org/assets/docs/A-Guide-toFour-Cs.pdf 
[3] Ö. Kutlu, S-K Kartal, The Prominent Student Competences of The 21st Century Education and The Transformation of Classroom Assessment, International Journal of Progressive Education 14 (2018) 71-74. DOI: https://doi.org/10.29329/ijpe.2018.179.6

[4] B. Sugiharto, Analisis pemahaman guru terkait pengembangan perangkat pembelajaran berbasis model quantum learning dan permasalahan siswa terkait dengan keterampilan berpikir kritis siswa dalam pembelajaran biologi SMA, in: Prosiding Seminar Nasional Pendidikan Biologi, vol. 4, Universitas Mataram, Mataram, 2018, pp. 611616

[5] F-N. Ayuni, Pemahaman Guru terhadap Pendekatan Saintifik (Scientific Approach) dalam Pembelajaran Geografi, Jurnal Geografi Gea $15 \quad$ (2016) 1-7. DOI: https://doi.org/10.17509/gea.v15i2.3542

[6] A-P. Heny, I-S. Mercuriani, An Analysis on The Achievement of Biology Cognitive Process and Product of Grade Eleven Students in Kulon Progo Based on The Teacher's Teaching Experience, International Journal of Social Sciences \& Educational Studies 4 (2018) 5. DOI: https://doi.org/10.23918/ijsses.v4i5p1

[7] E. Zakaria, M.J. Yaakob, S.M. Maat, M. Adnan, Conceptual knowledge and mathematics achievement of matriculation students, in: Procedia Social and Behavioral Sciences, vol. 9, Elsevier, Amsterdam, 2010, pp. 1020-1024. DOI: https://doi.org/10.1016/j.sbspro.2010.12.279

[8] B.D. Alonge, K.A. Olayinka, Teachers' Teaching Experience and Educational Qualification as Correlates of Academic Performance of Students in Public Secondary Schools in Ekiti State Nigeria, Journal of Education Practice 11 (2020) 108-110. DOI: https://doi.org/10.7176/JEP/11-2-12

[9] A. Rodríguez, S. McKay, Professional Development for Experienced Teachers Working with Adult English Language Learners, Caela Network Brief, May 2010, pp. 1-8. Accessed on: Oct. 2020, [Online]. Available: http://eric.ed.gov/?id=ED540598

[10] F.R. Rahim, D. Djamas, Analysis of Preliminary Understanding of High School Physics Teachers in Padang Pariaman Regency on Scientific Teaching Materials, Pelita Eksata Journal of Mathematics and Sciences Community Engagement 2 (2019) 115-120.

[11] D. Juandi, N. Priatna, Discovery learning model with geogebra assisted for improvement mathematical visual thinking ability, in: Journal of Physics: Conference Series, vol. 1013, IOP Publishing, Bristol, 2018, pp. 1-6. DOI: https://doi.org/10.1088/17426596/1013/1/012209

[12] W-V. Joolingen, Cognitive Tools for Discovery Learning, International Journal of Artificial Intelligence in Education (2008) 385-397

[13] I-Y-H. Manapa, Budiyono, S. Subanti, The experiment of cooperative learning model type team assisted individualization (TAI) on threedimensional space subject viewed from spatial intelligence, in: Journal of Physics: Conference Series, vol. 983, IOP Publishing, Bristol, 2018 pp. 1-7. DOI: https://doi.org/10.1088/1742$\underline{6596 / 983 / 1 / 012136}$

[14] D.R. Wilujeng, S. Sukamto, E. Eka Subekti, Team Assisted Individualization Model Assisted by Effective Ludo Media Improving Student Learning Outcomes, Journal of Education Technology 4 (2020) 377-384. DOI: https://doi.org/10.23887/jet.v4i3.27794

[15] S. Ramdiah, A. Abidinsyah, M. Royani, H. Husamah, Understanding, Planning, and Implementation of HOTS by Senior High School Biology Teachers in BanjarmasinIndonesia, International Journal of Instruction 12 (2019) 425-440. DOI: https://doi.org/10.29333/iji.2019.12128a

[16] L-W. Anderson, D.R. Krathwohl, P.W. Airasian, K.A. Cruikshank, R.E. Mayer, P.R. Pintrich, J. Raths, M.C. Wittrock, A Taxonomy for Learning, Teaching, and Assessing, Longman, 2001.

[17] P. Paidi, I.S. Mercuriani, B. Subali, Students' Competence in Cognitive Process and Knowledge in Biology Based on Curriculum Used in Indonesia, International Journal of Instruction 13 (2020) 491-510. DOI: https://doi.org/10.29333/iji.2020.13334a

[18] Z. Ünal, A. Ünal, The Impact of Years of Teaching Experience on The Classroom Management Approaches of Elementary School 
Teachers, International Journal of Instruction 5 (2012) 42-53

[19] M. Çakmak, Learning from Teaching Experiences: Novice Teachers' Thoughts, Journal of Education (2013) 55-66

[20] Y. Yusrizal, C.Z. Harun, H. Husen, M. Iqbal, Performance Assessment of State Senior High School Teachers Aged 56 Years and Above, International Journal of Instruction 11 (2018) 33-46,

DOI: https://doi.org/10.12973/iji.2018.1113a

[21] P-J-O. Aloka, O. Bojuwoye, Gender, Age and Teaching Experiences Differences in DecisionMaking Behaviours of Members of Selected Kenyan Secondary School Disciplinary Panels, Asian Social Science 9 (2013) 43-55. DOI: https://doi.org/10.5539/ass.v9n10p43

[22] V. Isari, Z-M. Efendi, N. Suhaili, Perbedaan Latar Belakang Pendidikan dan Masa Kerja
Guru Bimbingan dan Konseling terhadap Pelaksanaan Layanan Bimbingan dan Konseling Format Klasikal, Bikotetik (Bimbingan dan Konseling Teori dan Praktik) 1 (2017) 21-27. DOI: https://doi.org/10.26740/bikotetik.v1n1.p21-29

[23] C-A. Wolters, S-G. Daugherty, Goal Structures and Teachers' Sense Of Efficacy: Their Relation and Association to Teaching Experience and Academic Level, Journal of Educational Psychology 99 (2007) 181-191. DOI: https://doi.org/10.1037/0022$\underline{0663.99 .1 .181}$

[24] D-K-H. Khashan, Conceptual and Procedural Knowledge of Rational Numbers for Riyadh Elementary School Teachers, Journal of Education and Human Development 3 (2014) 181-197.

DOI: https://doi.org/10.15640/jehd.v3n4a17 